\title{
Evaluation of Cardiovascular Risk Factors in a Young Adults Tunisian Group
}

\author{
Lamine Oussama, Aboulkacem Sana, Grira Nedra, Ayoub Manel, Sendesni Rihab, \\ El Oudi Mabrouka, Stambouli Nejla, Mazigh Chakib, Aouni Zied*
}

Biochemistry Department, Military Hospital of Tunis, Tunis, Tunisia

Email: *aouni_zied@yahoo.fr

How to cite this paper: Oussama, L., Sana, A., Nedra, G., Manel, A., Rihab, S., Mabrouka, E.O., Nejla, S., Chakib, M. and Zied, A. (2018) Evaluation of Cardiovascular Risk Factors in a Young Adults Tunisian Group. Journal of Biosciences and Medicines, 6, 1-14. https://doi.org/10.4236/jbm.2018.63001

Received: November 27, 2017

Accepted: March 4, 2018

Published: March 7, 2018

Copyright $\odot 2018$ by authors and Scientific Research Publishing Inc. This work is licensed under the Creative Commons Attribution International License (CC BY 4.0).

http://creativecommons.org/licenses/by/4.0/

(c) (i) Open Access

\begin{abstract}
Introduction: Cardiovascular diseases have become more common in young adults. Their emergence is due to the prevalence of cardiovascular risk factors. The aim of this study is to determine the prevalence of cardiovascular risk factors in a Tunisian young adult group. Material and methods: This is an epidemiological study of 705 Tunisians volunteers, free from any cardiovascular pathology; who are recruited at the Military Hospital of Tunis. Besides the classical cardiovascular risk factors (obesity, dyslipidemia, smoking, alcohol...), we evaluate the level of homocysteinemia and determined the C677T mutation of the methylenetetrahydrofolate reductase (MTHFR) gene by PCR-RFLP method. Results and conclusions: The mean age of our population is $28.25 \pm 9.08$ with a male majority (83.8\%). We have $43.8 \%$ obese subject or overweight, $54.3 \%$ smokers and $12.9 \%$ alcoholics. The lipid profile showed that $12.6 \%$ of the population had hypercholesterolemia and $39.5 \%$ had hypoHDLemia, $7.9 \%$ had a high lipoprotein(a) concentration. In our study population we found that $10.9 \%$ of subjects had an hs-CRP concentration greater than $3 \mathrm{mg} / \mathrm{L}$. Genotyping of the MTHFR gene revealed that $34 \%$ of young adults had a mutated genome (CT). The results showed a significant correlation between different factors, such as cholesterolemia and obesity. The prevalence of these risk factors showed the severity of our young people's health status and imposes a change in the way of Tunisians life.
\end{abstract}

\section{Keywords}

Young Adult, Dyslipidemia, Cardiovascular Risk, Cholesterolemia

\section{Introduction}

Cardiovascular disease (CVD) is the leading cause of mortality from chronic 
disease. According to WHO data made in 2012, around 17.5 million deaths attributable to CVD. It is considered that 23.3 million people could die from cardiovascular events in 2030 [1]. The occurrence of CVD is mainly due to an increase in the prevalence of cardiovascular risk factors, such as smoking, sedentary lifestyle, diabetes, stress and changing dietary habits. In the recent years, the mean age of CVD emergence has been decreased outstandingly. Indeed, the prevalence of CVD continues to increase in young adults. In 2014, according to a review published by Maaijwee N.A et al. [2], about $10 \%$ of all strokes occur in people under the age of 50 years.

Since the last decades, Tunisia has gone through an epidemiological transition phase, characterized by a decline in communicable diseases and a steady rise in chronic diseases such as cancers, diabetes, respiratory diseases and especially CVD [3]. Indeed, in 2014, 49\% of total deaths are due to CVD [4]. The incidence of these diseases is clearly increasing due to the aging of the Tunisian population and exposure to certain risk factors such as smoking, hypertension, dyslipidemia and obesity [3].

\section{Material and Methods}

\subsection{Study Population}

This study was carried out among 705 Tunisian volunteers subjects free from any cardiovascular pathology whose mean age is $28.25 \pm 9.08$.

The study was approved by the ethics committee of the military hospital and all participants gave their informed consent. The data collection was carried out by a qualified person on the basis of a questionnaire previously established and tested, comprising several data items.

\subsection{Sampling and Determination of Biological Parameters}

The blood samples were taken in the morning on fasting for the determination of biological constants and the determination of genetic polymorphism.

The homocysteine (Hcy) harvest was collected in a tube containing EDTA and placed in ice, thereafter it was centrifuged in 15 minutes at $3000 \mathrm{rpm}$. The total Hcy level was determined by the Immunite ${ }^{\circledR}$ analyzer (Siemens, Germany) based on a competitive immunoassay. While testing of total cholesterol (TC), triglycerides (TG) and HDL-c was carried out using the enzymatic colorimetric method on the DxC800 Synchron ${ }^{\circledR}$ (Beckman Coulter, USA). The LDL-c concentration was determined by Friedwald's formula.

The ApoAI, ApoB, Lp (a) and hs-CRP concentration was determined using an immunonephelometric method on a BNII ${ }^{\circledR}$ nephelometric analyzer (Siemens, Germany).

\subsection{Genetics Analysis}

Genotyping of MTHFR C677T (rs1801133) polymorphism was accomplished by polymerase chain reaction followed by restriction fragments length polymor- 
phism method (PCR-RFLP). Genomic DNA was isolated from peripheral blood by the salting out method. To identify the MTHFR C677T polymorphism, a 270 bp fragment was amplified using the forward primer 5'GCCAGCCTCTCCTGA CTGTC3' and the reverse primer 5'AGTGGGGTGGAGGGAGCTTA3'. The conditions of the reaction were as follows: denaturation at $94^{\circ} \mathrm{C}$ for 60 seconds, followed by 40 cycles of annealing at $65^{\circ} \mathrm{C}$ for 1 minute, extension at $72^{\circ} \mathrm{C}$ for 60 seconds, and a final elongation step at $72^{\circ} \mathrm{C}$ for 5 minutes.

The amplified products were digested with Hinfl enzyme for $12 \mathrm{~h}$ at least, at $37^{\circ} \mathrm{C}$. The polymorphism created a recognition site for the enzyme so that the initial PCR product $(270 \mathrm{bp}$ ) was cut into two fragments (160 and $110 \mathrm{bp}$ ) in the presence of the $677 \mathrm{~T}$ allele. The restriction fragments were separated by electrophoresis in 3\% agarose gel and visualized by red safe staining.

\subsection{Statistical Analysis}

All statistical analysis were performed using SPSS software version 20.0 (SPSS Inc, USA) for Windows (Microsoft Corporation, USA). All data were expressed as percentages or mean \pm standard deviation (SD). The quantitative variables were compared by Student $\mathrm{t}$-test, the qualitative data by the chi-square test. The Spearman test was used to study the correlation between the different parameters studied. A $p$ value less than 0.05 was taken as a statistically significant.

\subsection{Ethic Statements}

This study has already been approved by Ethic committee of Tunis military hospital. All subjects including in the study were signed an informed consent after explaining in detail the study objectives and procedure.

\section{Results}

Our population consisted predominantly of young adults; the mean age is 28.25 \pm 9.08 with a masculine predominance. The study population characteristics are showed in Table 1.

A significant difference was found between men and women in terms of consuming alcohol, tobacco smoking and family history of CVD. The mean values of triglycerides, HDL-c, LDL-c, ApoA1 and ApoB were significantly different between both genders.

\section{- The MTHFR C677T gene Polymorphism}

We studied the genetic polymorphism of the MTHFR gene and the results are showed in Figure 1.

\section{- High-sensitivity C-reactive protein (hs-CRP)}

The subjects included in our study were assisted by hs-CRP assay to assess cardiovascular risk. The subjects were divided into three groups according to the hs-CRP values (Figure 2).

We have subdivided our population according to BMI into two groups (group $1:$ BMI $\leq 25 \mathrm{~kg} / \mathrm{m}^{2}$, group $2: \mathrm{BMI}>25 \mathrm{~kg} / \mathrm{m}^{2}$ ). Statistical analysis showed a sig- 
nificant difference in TC, TG, LDLc and ApoB values (Table 2).

In order to better understand the relationship between the different factors we studied the Pearson correlation and the results are showed in Figure 3.

Table 1. Study population characteristics.

\begin{tabular}{|c|c|c|c|c|}
\hline $\begin{array}{c}\text { Characteristics } \\
\text { mean } \pm \mathrm{SD}\end{array}$ & $\begin{array}{l}\text { Study group } \\
\qquad \mathrm{n}=705\end{array}$ & $\begin{array}{c}\text { Men } \\
\mathrm{n}=541\end{array}$ & $\begin{array}{l}\text { Women } \\
\mathrm{N}=114\end{array}$ & $p$ \\
\hline \multicolumn{5}{|l|}{ General parameters } \\
\hline Age (yrs), & $28.25 \pm 9.08$ & $27.3 \pm 8.5$ & $33.1 \pm 8.9$ & $<10^{-3}$ \\
\hline $\mathrm{BMI}\left(\mathrm{Kg} / \mathrm{m}^{2}\right)$ & $24.42 \pm 3.35$ & $24.42 \pm 3.2$ & $24.40 \pm 4.1$ & NS \\
\hline Tobacco Smoking (\%) & 54.3 & 53.8 & - & - \\
\hline Alcohol drinking (\%) & 12.9 & 12.9 & - & - \\
\hline Family history of CVD (\%) & 21.1 & 15.1 & 6.0 & $<10^{-3}$ \\
\hline \multicolumn{5}{|l|}{ Biological parameters } \\
\hline $\mathrm{TC}(\mathrm{mmol} / \mathrm{l})$ & $3.98 \pm 1.05$ & $3.9 \pm 1.01$ & $4.1 \pm 1.05$ & 0.17 \\
\hline $\mathrm{TG}(\mathrm{mmol} / \mathrm{l})$ & $1.39 \pm 0.7$ & $1.58 \pm 1.02$ & $0.55 \pm 0.08$ & $<10^{-3}$ \\
\hline HDL-c (mmol/l) & $0.978 \pm 0.282$ & $0.96 \pm 2.27$ & $1.04 \pm 0.31$ & 0.003 \\
\hline LDL-c (mmol/l) & $2.34 \pm 0.91$ & $2.27 \pm 0.91$ & $2.68 \pm 0.87$ & $<10^{-3}$ \\
\hline ApoA1 (mg/l) & $1.91 \pm 0.27$ & $1.15 \pm 0.24$ & $1.39 \pm 0.33$ & $<10^{-3}$ \\
\hline ApoB (mg/l) & $0.74 \pm 0.266$ & $0.71 \pm 0.21$ & $0.32 \pm 0.03$ & $<10^{-3}$ \\
\hline ApoB/apoA1 & $0.63 \pm 0.32$ & $0.63 \pm 0.22$ & $0.67 \pm 0.63$ & 0.75 \\
\hline $\mathrm{Lp}(\mathrm{a})(\mathrm{mg} / \mathrm{l})$ & $0.11 \pm 0.07$ & $0.11 \pm 0.05$ & $0.14 \pm 0.01$ & 0.39 \\
\hline
\end{tabular}

SD: standard deviation; BMI: body mass index; LDL-c: low density lipoprotein cholesterol; HDL-c: high density lipoprotein cholesterol; ApoA1: Apolipoprotein A1; ApoB: Apolipoprotein B; Lp(a): Lipoprotein a; TC: total cholesterol; TG: triglyceride.

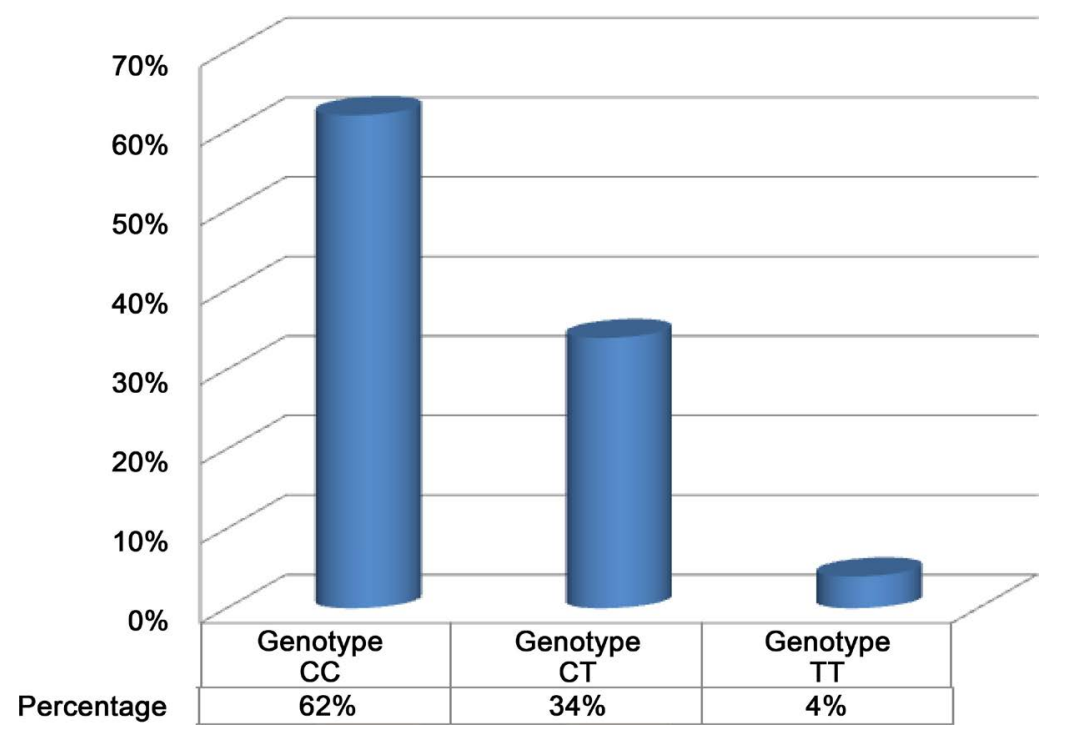

Figure 1. Genotypes frequency of MTHFR C677T gene polymorphism. 


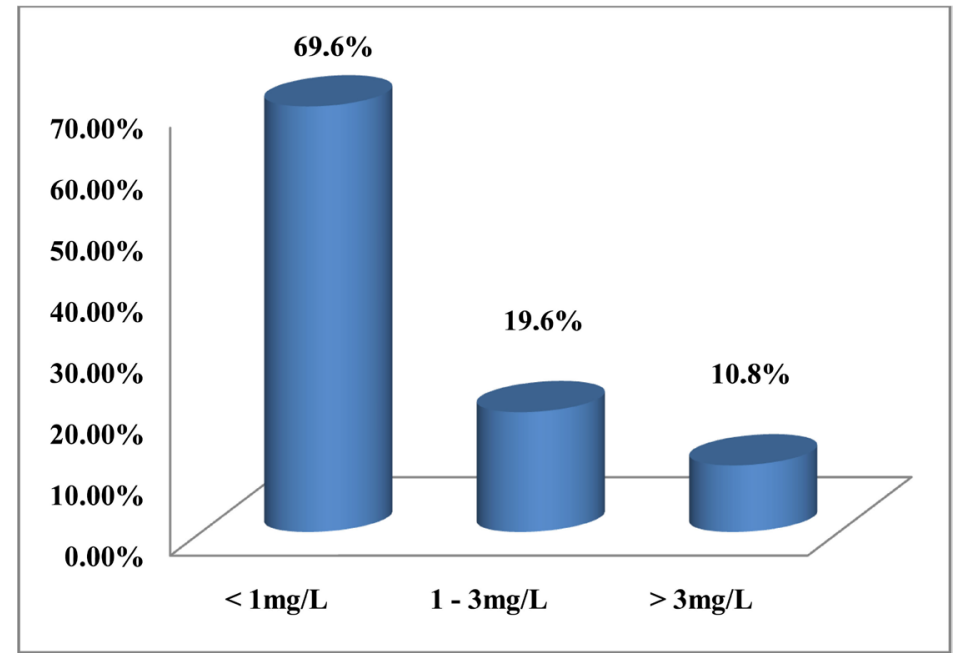

Figure 2. Distribution of population by hs-CRP concentration.

Table 2. Association between the different CVD risk factors.

\begin{tabular}{|c|c|c|c|c|}
\hline & & $\mathrm{BMI}>25$ & $\mathrm{BMI} \leq 25$ & $p$ \\
\hline \multicolumn{5}{|c|}{ Epidemiological parameters } \\
\hline \multirow{2}{*}{$\operatorname{Sex}(\%)$} & M & $43.97 \%$ & $56.03 \%$ & 0.918 \\
\hline & $\mathrm{W}$ & $42.98 \%$ & $57.02 \%$ & - \\
\hline \multirow{2}{*}{ Tobacco Smoking (n) } & yes & 144 & 237 & 0.001 \\
\hline & No & 164 & 158 & - \\
\hline \multirow{2}{*}{ Alcohol drinking (n) } & yes & 275 & 338 & 0.172 \\
\hline & No & 33 & 57 & - \\
\hline Age & & $31.82 \pm 9.564$ & $25.49 \pm 7.637$ & $<10^{-3}$ \\
\hline \multicolumn{5}{|c|}{ Biological parameters } \\
\hline $\mathrm{TC}(\mathrm{mmol} / \mathrm{l})$ & & $4.338 \pm 1.187$ & $3.725 \pm 0.842$ & $<10^{-3}$ \\
\hline $\mathrm{TG}(\mathrm{mmol} / \mathrm{l})$ & & $1.68 \pm 1.12$ & $1.31 \pm 0.86$ & $<10^{-3}$ \\
\hline HDL-c (mmol/l) & & $1.02 \pm 0.29$ & $0.94 \pm 0.27$ & 0.001 \\
\hline LDL-c (mmol/l) & & $2.55 \pm 1.03$ & $2.17 \pm 0.77$ & $<10^{-3}$ \\
\hline $\operatorname{Lp}(\mathrm{a})(\mathrm{g} / \mathrm{l})$ & & $0.112 \pm 0.116$ & $0.119 \pm 0.116$ & 0.45 \\
\hline ApoA1 (g/l) & & $1.21 \pm 0.26$ & $1.17 \pm 0.28$ & 0.093 \\
\hline ApoB (g/l) & & $0.82 \pm 0.3$ & $0.67 \pm 0.21$ & $<10^{-3}$ \\
\hline $\mathrm{Hcy}(\mu \mathrm{mol} / \mathrm{l})$ & & $12.86 \pm 5.5$ & $12.3 \pm 4.93$ & 0.15 \\
\hline
\end{tabular}

p. significance; n: number; BMI: body mass index; TG: triglyceride; TC: total cholesterol; LDL-c: low density lipoprotein cholesterol; HDL-c: high density lipoprotein cholesterol; ApoA1: Apolipoprotein A1; ApoB: Apolipoprotein B; Lp(a): Lipoprotein a; Hcy: homocycteine.

\section{Discussion}

\section{- The sex}

The aim of our study was to evaluate cardiovascular risk factors in 705 young subjects that the majority of whom are male. According to the World Health 


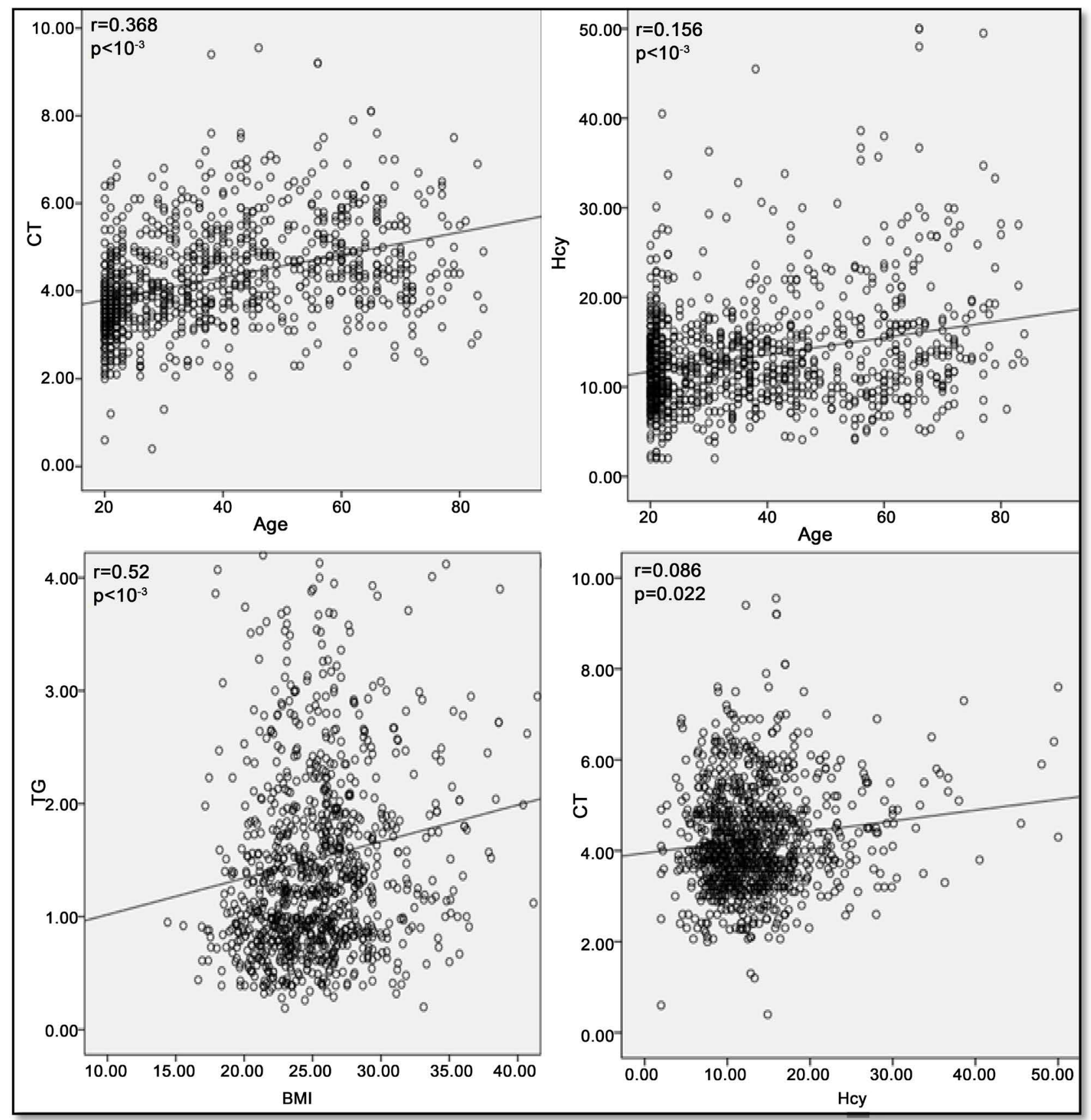

$\mathrm{r}=$ Pearson correlation; $p$ : significance; BMI: body mass index; Hcy: homocycteine; TG: triglyceride; TC: total cholesterol Figure 3. Correlation between CVD risk factors.

Organization (WHO) statistics [4], men die more than women due to CVD in Tunisia and women are more affected by obesity, while men consume more tobacco and alcohol.

\section{- The age}

The mean age of our population was $28.25 \pm 9.08$, they were young subjects with no pathologies. This age group was increasingly affected by cardiovascular risk factors. A Tunisian study [3] showed that adults aged between 35 and 44 years had a high frequency of risk factors (RF) with $41 \%$ obesity in women and 
$76 \%$ smoking in men. This early manifestation of RF is due to a change in dietary habits from childhood to adolescence [5].

\section{- Body mass index}

In our study, the mean BMI varies between $19 \mathrm{~kg} / \mathrm{m}^{2}$ and $37.8 \mathrm{~kg} / \mathrm{m}^{2}$. These results were similar to the study of Sozmen et al. [6] in which the mean BMI was calculated for four countries in the Eastern Mediterranean region: Tunisia, Turkey, Syria and Palestine. The four countries showed an increased mean BMI between 1997 and 2009 for both sexes, with $28.4 \mathrm{~kg} / \mathrm{m}^{2}$ mean value for Tunisian in 2009 , this result was explained by the change in lifestyle that becomes more sedentary with a trend towards fast food.

Our results analysis showed that $43.8 \%$ of studied population was obese or overweight. This percentage was closed to those found in the study of Uvcsek et al. [7] in which $42 \%$ and $38 \%$ of American and Hungarian students respectively were obese. Our result exceeded those found in China [8] and India [9] in the same age group. However, a higher frequency was observed in Portugal [10] and in the United States.

\section{- Smoking and alcohol consumption}

More than half of subjects in our study were smokers (54.3\%), this prevalence was considered high compared to other countries such as Saudi Arabia [11], Senegal [12] and Thailand [13]. Our results were consistent with those found by the WHO [4] where 52\% of men were smokers in 2011. Smoking is considered to be one of the main risk factors of CVD by an inflammatory mechanism; it participates in the initiation of atherosclerosis by increasing the oxidation of LDL-c [14].

Our results showed that $12.9 \%$ of the subjects regularly consume alcohol, a very low percentage compared to the Cameroonians [15] and the French [16]. Indeed, in France, more than half (52\%) of young people between 15 and 24 years old regularly consume alcohol.

\section{- Family history of CVD}

In our study, $21.1 \%$ of subjects had a family history of CVD. This percentage is low compared to other European populations. Indeed, Ineke van Dis et al. [17] reported that in a Germany population, 36\% of the subjects present familial CVD with a risk of $30 \%$ to $60 \%$ higher than the subjects without family ATCD.

It has even been demonstrated that the earlier appearance of CVD enhance the risk for the progeny [18] [19]. In this context, Pessinaba et al. [12] showed that the presence of a family history of diabetes increased the risk to be diabetic by a factor of 2.3 .

\section{- Lipid profile}

The mean concentration of cholesterol in our study was in the usual range. Among our population $12.5 \%$ had hypercholesterolemia and our result was closed to the result found by a survey carried out in Algeria [20] in a set of subjects aged 25 and over. This percentage remains below the prevalence in Senegal (36.3\%) [12], in Thailand (60\%) [13], and above the Bangladesh hypercholeste- 
rolemia [21] 5.8\% for people aged between 35 and 44 years.

Hypercholesterolemia is one of the factors that cause endothelium dysfunction [22] and is the cause of increased oxidative stress and the creation of an inflammatory state that is responsible for impairment of the functioning of the vascular system [23]. A lowering of cholesterol could therefore reduce the risk of coronary diseases; in fact it had been shown that a decrease of $1 \mathrm{mmol} / \mathrm{l}$ of cholesterol could decrease by one half, one-third and one-sixth of coronary mortality [24].

Our study population comprised $11.8 \%$ of subjects with a LDL-c concentration higher than $3.4 \mathrm{mmol} / \mathrm{ml}$. We had $39.5 \%$ of subjects with HDL-c $<1.05$ $\mathrm{mmol} / \mathrm{L}$, a result consistent with that found in a population in Puerto Rico [25] and also in a Senegalese population [12]. On the other hand, the study of Gordon-Larsen et al. [26] showed a lower frequency where $26.3 \%$ of Chinese had a hypoHDLemia. HDLc play a protective role in CVD [22], and are known by their anti-inflammatory, antithrombotic, antiproliferative and antioxidant properties [27].

Among our population, $24.7 \%$ had hypertriglyceridemia, and a similar result was found in the study of Chatti et al. [28] who reported a hypertriglyceridemia in $25.9 \%$ of unstamped workers.

Our results were also similar to a Chinese study [29] where $24.38 \%$ of a group of Mulao had TG concentrations higher than $1.7 \mathrm{mmo} / \mathrm{L}$. Physical inactivity and obesity would be the cause of this metabolic disturbance. A lower frequency of hypertriglyceridemia was found in Algeria [20] and Senegal [12]. There is a strong association between plasma triglyceride concentration and the acceleration of the atherosclerotic process [30].

\section{- Second-line lipid profile}

The mean concentrations of ApoA and $A p o B$ in the subjects of our study were respectively $1.19 \pm 0.27 \mathrm{~g} / \mathrm{l}$ and $0.74 \pm 0.26 \mathrm{~g} / \mathrm{l}$, very similar values were reported in the study of Pan et al. [31] in normal subjects.

ApoA1 plays a protective role. It is the main constituent of HDL lipoproteins and interacts with its receptors to ensure the reverse transport of excess cholesterol at the peripheral level [32]. Unlike ApoA1, ApoB and more precisely ApoB100 is the main structural component of LDL particles [33]. On the other hand, apoA1 had an anti-inflammatory and antioxidant effect [33]. Our results showed that $37.4 \%$ of subjects had a low apoAl concentration and $17.6 \%$ had ApoB values above normal.

Several studies had investigated the relationship between ApoA1 and ApoB concentrations and increased risk of CVD [34] [35]. The mean ApoB/ApoA1 ratio of our population is $0.63 \pm 0.32$, a similar mean had been described in the study of Wanhua Xu et al. [36]. In this context several epidemiological studies had shown that there was a remarkable linear relationship between this ratio and the risk of acute myocardial infarction [37]. Indeed, a high ApoB/ApoA1 ratio is responsible for increasing the risk of myocardial infarction by about $50 \%$ [38]. 
The mean concentration of $\mathrm{Lp}$ (a) in our population is $0.11 \mathrm{~g} / \mathrm{l}$. An approaching value found in a China cohort study [39] with an average of $0.14 \mathrm{~g} / \mathrm{l}$ in the control group, whereas the group with acute ischemic stroke had a higher mean $(0.32 \mathrm{~g} / \mathrm{l})$. There was a positive correlation between the mean Lp (a) concentration and the occurrence of ischemic stroke or death state of coronary origin [40].

The concentration of Lp (a) higher than $0.3 \mathrm{~g} / \mathrm{l}$ would be responsible for the increased risk of acute ischemic stroke [39] and deep venous thrombosis [41]. In our study, $7.9 \%$ of subjects had a concentration higher than $0.3 \mathrm{~g} / \mathrm{l}$. A low frequency compared to the study of Joussein-Remacle et al. [42] in which $41.7 \%$ of subjects less than 55 years had a high Lp (a) concentration. The Copenhagen study showed that a value of Lp (a) $>5 \mathrm{~g} / \mathrm{l}$ increases the risk of myocardial infarction by 2 to 3 times [43].

Forbang et al. [44] had also showed the association between a high Lp (a) concentration and peripheral arterial disease. Lp (a) also called LDL-like is a combination of an Apo A covalently bonded to the surface of an ApoB main component of LDL-c [45]. The structural similarity of ApoA with plasminogen and the atherogenic character of $A p o B$ mean that $\mathrm{Lp}(\mathrm{a})$ is involved in two phenomena: the atherosclerosis and the thrombosis [46] [47]. Lp (a) is also involved in the inhibition of a growth factor (TGF-b) which leads to the proliferation of smooth muscle cells in the intima enhancing the formation of atheroma plaques [46].

\section{- High-sensitivity C-reactive protein (hs-CRP)}

Inflammation plays an important role in the development of atherosclerosis and its complications [48]. Among the inflammatory markers the hs-CRP is the most dosed marker. It is a hepatic origin protein whose concentration increased during the inflammatory states. Several studies had shown the importance of the hs-CRP as a risk factor independent of CVD [49] [50].

Our study population was divided into 3 risk levels according to the hs-CRP concentration: $69.6 \%$ had a low risk of CVD, $19.6 \%$ had a moderate risk and $10.9 \%$ had a significant risk. Our results were similar to those reported in the Japanese study of Saito et al. [51] where $10.6 \%$ of subjects had a low risk of developing CVD. The Subjects who had high hs-CRP values had another associated risk factor such as diabetes, hypertension and obesity.

\section{- Association between the different risk factors}

Our results also showed a correlation between BMI and lipids. A high mean TC, TG and LDL-c were observed in obese or overweight people. These findings had been reported in a study of a Turkish adult population [52], where the prevalence of dyslipidemia is significantly correlated with high BMI values.

In addition to age, Hcy is also positively correlated with other risk factors such as dyslipidemia. High levels of Hcy were associated with hypercholesterolemia and hypertriglyceridaemia within our study population. The results which are in line with those found in the study of Chellak et al. [53] in 2045 military subjects, were showed synergistic linkage of Hcy with CT and TG in the maintenance of 
atherosclerosis. Indeed abnormal concentrations of Hcy promote atherogenesis in three ways [54]: by a direct toxic effect on the cells of the internal wall of the arteries, by proliferation of the smooth muscle cells and by the oxidation of the LDL-c.

The correlation results of our study confirmed that the development of atherosclerosis was due to an interaction between different risk factors. It was a complex process that evolves slowly in which the classical and emergent risk factors interact with each other and between the arterial walls.

\section{Conclusions}

The evaluation of risk factors in our study population allowed us to detect many abnormalities that were genetic, physiological or behavioral. Despite the young age of our subjects, the incidence of certain risk factors was high. Smoking and overweight are the main risk factors. Indeed, more than half of the subjects included in this study are smokers; similarly $43.5 \%$ of the studied population is overweight or obese. Abnormalities of lipid metabolism (hypertriglyceridaemia and hypercholesterolemia) are also common and present a real health problem in the Tunisian population.

The stress, work and routine have made people careless about their health; the perception of risk is virtually absent. Thereby, awareness and prevention efforts must be multiplied and involve several stakeholders: school education program, health and media protocols.

Finally, despite efforts to prevent cardiovascular disease, the solution lies in the person himself. The perception and awareness of the danger of some habits may involve will and challenge.

\section{Acknowledgements}

The authors thank all those who collaborated in the analysis, interpretation of data, writing of the article and all technicians of the biochemistry lab in Tunis military hospital.

\section{References}

[1] Organisation Mondiale de la Santé (2015) Maladies cardiovasculaires [En Ligne]. [Consulté le 4 avril 2015]. http://www.who.int/mediacentre/factsheets/fs317/fr/

[2] Maaijwee, N.A., Rutten-Jacobs, L.C., Schaapsmeerders, P., Van Dijk, E.J. and de Leeuw, F.E. (2014) Ischaemic Stroke in Young Adults: Risk Factors and Long-Term Consequences. Nature Reviews Neurology, 10, 315-325.

https://doi.org/10.1038/nrneurol.2014.72

[3] Elasmi, M., Feki, M., Sanhaji, H., Jemaa, R., Haj Taeib, S., Omar, S., et al. (2009) Prévalence des facteurs de risque cardiovasculaires conventionnels dans la population du Grand Tunis. Revue d'Epidémiologie et de Santé Publique, 57, 87-92. https://doi.org/10.1016/j.respe.2008.12.010

[4] Organisation Mondiale de la Santé (2014) Tunisia [En Ligne]. [Consulté le 4 avril 2015]. http://www.who.int/nmh/countries/tun_en.pdf?ua=1 
[5] Aounallah-Skhiri, H., Romdhane, H.B., Traissac, P., Eymard-Duvernay, S., Delpeuch, F., Achour, N., et al. (2008) Nutritional Status of Tunisian Adolescents: Associated Gender, Environmental and Socio-Economic Factors. Public Health Nutrition, 11, 1306-1317. https://doi.org/10.1017/S1368980008002693

[6] Sozmen, K., Unal, B., Saidi, O., Ben Romdhane, H., Abu-Rmeileh, N.M., Husseini, A., et al. (2015) Cardiovascular Risk Factor Trends in the Eastern Mediterranean Region: Evidence from Four Countries Is Alarming. International Journal of Public Health, 60, S3-11. https://doi.org/10.1007/s00038-014-0610-6

[7] Uvacsek, M., Kneffel, Z., Toth, M., Johnson, A.W., Vehrs, P., Myrer, J.W., et al. (2014) Ten-Year Cardiovascular Risk Assessment in University Students. Acta Physiologica Hungarica, 101, 321-328.

https://doi.org/10.1556/APhysiol.101.2014.3.7

[8] Wan, Y., Jiang, X., He, Y., Zhang, Y., Liang, Y., Pan, F., et al. (2016) Body Mass Index of Young Men in China: Results from Four National Surveys Conducted between 1955 and 2012. Medicine, 95, e2829.

https://doi.org/10.1097/MD.0000000000002829

[9] Meshram, I.I., Vishnu Vardhana Rao, M., Sudershan Rao, V., Laxmaiah, A. and Polasa, K. (2016) Regional Variation in the Prevalence of Overweight/Obesity, Hypertension and Diabetes and Their Correlates among the Adult Rural Population in India. British Journal of Nutrition, 115, 1265-1272. https://doi.org/10.1017/S0007114516000039

[10] Carreira, H., Pereira, M., Azevedo, A. and Lunet, N. (2012) Trends of BMI and Prevalence of Overweight and Obesity in Portugal (1995-2005): A Systematic Review. Public Health Nutrition, 15, 972-981. https://doi.org/10.1017/S1368980012000559

[11] Moradi-Lakeh, M., El Bcheraoui, C., Tuffaha, M., Daoud, F., Al Saeedi, M., Basulaiman, M., et al. (2015) Tobacco Consumption in the Kingdom of Saudi Arabia, 2013: Findings from a National Survey. BMC Public Health, 15, 1-10. https://doi.org/10.1186/s12889-015-1902-3

[12] Pessinaba, S., Mbaye, A., Yabeta, G.A., Harouna, H., Sib, A.E., Kane, A.D., et al. (2013) Prevalence Survey of Cardiovascular Risk Factors in the General Population in St. Louis (Senegal). Annales de Cardiologie et D'Angeiologie, 62, 253-258. https://doi.org/10.1016/j.ancard.2013.02.005

[13] Palangrit, S. and Muengtaweepongsa, S. (2015) Risk Factors of Stroke in Pathumthani Province, Thailand. Journal of the Medical Association of Thailand, 98, 649-655.

[14] Merhi, M., Demirdjian, S., Hariri, E., Sabbah, N., Youhanna, S., Ghassibe-Sabbagh, M., et al. (2015) Impact of inflammation, Gene Variants, and Cigarette Smoking on Coronary Artery Disease Risk. Inflammation Research, 64, 415-422.

https://doi.org/10.1007/s00011-015-0821-1

[15] Epacka Ewane, M., Mandengue, S.H., Ahmadou, G., Moumbe Tamba, S., Dzudie, A. and Luma, H.N. (2011) Dépistage des maladies cardiovasculaires et des facteurs de risque dans une cohorte de 270 Camerounais: effets des activités physiques et sportives. Med Mal Metab., 5, 655-658. https://doi.org/10.1016/S1957-2557(11)70342-X

[16] Beck, F. and Richard, J.B. (2013) Epidémiologie de l'alcoolisation. Endocrinologie-Nutrition, 10, 1-9.

[17] van Dis, I., Kromhout, D., Boer, J.M., Geleijnse, J.M. and Verschuren, W.M. (2011) Paternal and Maternal History of Myocardial Infarction and Cardiovascular Dis- 
eases Incidence in a Dutch Cohort of Middle-Aged Persons. PLoS ONE, 6, e28697. https://doi.org/10.1371/journal.pone.0028697

[18] Weijmans, M., van der Graaf, Y., Reitsma, J.B. and Visseren, F.L. (2015) Paternal or Maternal History of Cardiovascular Disease and the Risk of Cardiovascular Disease in Offspring. A Systematic Review and Meta-Analysis. International Journal of Cardiology, 179, 409-416. https://doi.org/10.1016/j.ijcard.2014.11.017

[19] Sesso, H.D., Lee, I.M., Gaziano, J.M., Rexrode, K.M., Glynn, R.J. and Buring, J.E. (2001) Maternal and Paternal History of Myocardial Infarction and Risk of Cardiovascular Disease in Men and Women. Circulation, 104, 393-398. https://doi.org/10.1161/hc2901.093115

[20] Yahia-Berrouiguet, A., Benyoucef, M., Meguenni, K. and Brouri, M. (2011) Enquête sur la prévalence des facteurs de risque de maladies cardiovasculaires à Tlemcen (Algérie). Médecine des maladies Métaboliques, 5, 42-48. https://doi.org/10.1016/S1957-2557(11)70071-2

[21] Zaman, M.M., Choudhury, S.R., Ahmed, J., Talukder, M.H. and Rahman, A.H. (2016) Blood Glucose and Cholesterol Levels in Adult Population of Bangladesh: Results from STEPS 2006 Survey. Indian Heart Journal, 68, 52-56. https://doi.org/10.1016/j.ihj.2015.06.031

[22] Paul, J. and Baudin, B. (2009) Physiopathologie de l'athérosclérose et marqueurs précoces. Revue francophone des laboratories, 409, 41-50. https://doi.org/10.1016/S1773-035X(09)70199-6

[23] Stapleton, P.A., Goodwill, A.G., James, M.E., Brock, R.W. and Frisbee, J.C. (2010) Hypercholesterolemia and Microvascular Dysfunction: Interventional Strategies. Journal of Inflammation, 7, 54. https://doi.org/10.1186/1476-9255-7-54

[24] Prospective Studies Collaboration, Lewington, S., Whitlock, G., Clarke, R., Sherliker, P., Emberson, J., et al. (2007) Blood Cholesterol and Vascular Mortality by Age, Sex, and Blood Pressure: A Meta-Analysis of Individual Data from 61 Prospective Studies with 55000 Vascular Deaths. The Lancet, 370, 1829-1839. https://doi.org/10.1016/S0140-6736(07)61778-4

[25] Perez, C.M., Sanchez, H. and Ortiz, A.P. (2013) Prevalence of Overweight and Obesity and Their Cardiometabolic Comorbidities in Hispanic Adults Living in Puerto Rico. Journal of Community Health, 38, 1140-1146. https://doi.org/10.1007/s10900-013-9726-5

[26] Gordon-Larsen, P., Adair, L.S., Meigs, J.B., Mayer-Davis, E., Herring, A., Yan, S.K., et al. (2013) Discordant Risk: Overweight and Cardiometabolic Risk in Chinese Adults. Obesity, 21, E166-E174. https://doi.org/10.1002/oby.20409

[27] Bruckert, E., Farnier, M. and Ferrières, J. (2010) HDL-Cholestérol et risque cardiovasculaire: Au-delà du LDL. Médecine des maladies Métaboliques, 4, 379-388. https://doi.org/10.1016/S1957-2557(10)70081-X

[28] Chatti, S., Debbabi, F., Ben Abdelaziz, A., Harbaoui, R., Ghannem, H. and Mrizak, N. (2010) Cardiovascular Risk Factors among Shift Workers in Company of Electricity Production in the Centre of Tunisia. Annales de Cardiologie et d Angéiologie, 59, 190-195. https://doi.org/10.1016/j.ancard.2009.07.002

[29] Liao, P.J., Xie, R.B., Yin, R.X., Wei, D.X., Huang, J., Huang, F., et al. (2015) Serum Lipid Profiles, the Prevalence of Dyslipidemia and the Risk Factors in Two Isolated Chinese Minorities. International Journal of Clinical and Experimental Medicine, 8 19200-19211.

[30] Brinton, E.A. (2016) Management of Hypertriglyceridemia for Prevention of Atherosclerotic Cardiovascular Disease. Endocrinology Metabolism Clinics of North 
America, 45, 185-204. https://doi.org/10.1016/j.ecl.2015.09.012

[31] Pan, L., Lu, G. and Chen, Z. (2014) Combined Use of Apolipoprotein B/Apolipoprotein A1 Ratio and Non-High-Density Lipoprotein Cholesterol before Routine Clinical Lipid Measurement in Predicting Coronary Heart Disease. Coronary Artery Disease, 25, 433-438. https://doi.org/10.1097/MCA.0000000000000100

[32] Raitakari, O.T., Makinen, V.P., McQueen, M.J., Niemi, J., Juonala, M., Jauhiainen, M., et al. (2013) Computationally Estimated Apolipoproteins B and A1 in Predicting Cardiovascular Risk. Atherosclerosis, 226, 245-251. https://doi.org/10.1016/j.atherosclerosis.2012.10.049

[33] Andrikoula, M. and McDowell, I.F. (2008) The Contribution of ApoB and ApoA1 Measurements to Cardiovascular Risk Assessment. Diabetes, Obesity and Metabolism, 10, 271-278. https://doi.org/10.1111/j.1463-1326.2007.00714.x

[34] Gehani, A.A., Al-Hinai, A.T., Zubaid, M., Almahmeed, W., Hasani, M.R., Yusufali, A.H., et al. (2014) Association of Risk Factors with Acute Myocardial Infarction in Middle Eastern Countries: The Interheart Middle East Study. European Journal of Preventive Cardiology, 21, 400-410. https://doi.org/10.1177/2047487312465525

[35] Dong, H., Chen, W., Wang, X., Pi, F., Wu, Y., Pang, S., et al. (2015) Apolipoprotein A1, B Levels, and Their Ratio and the Risk of a First Stroke: A Meta-Analysis and Case-Control Study. Metabolic Brain Disease, 30, 1319-1330. https://doi.org/10.1007/s11011-015-9732-7

[36] Xu, W., Li, R., Zhang, S., Gong, L., Wang, Z., Ren, W., et al. (2012) The Relationship between High-Sensitivity C-Reactive Protein and ApoB, ApoB/ApoA1 Ratio in General Population of China. Endocrine, 42, 132-138. https://doi.org/10.1007/s12020-012-9599-x

[37] Walldius, G., Aastveit, A.H. and Jungner, I. (2006) Stroke Mortality and the apoB/apoA-I Ratio: Results of the AMORIS Prospective Study. Journal of Internal Medicine, 259, 259-266. https://doi.org/10.1111/j.1365-2796.2005.01610.x

[38] Scheen, A.J. and Kulbertus, H. (2004) L'étudde clinique du mois INTERHEART: La preuve par 9 Neuf facteurs de risque prédisent neuf infarctus du myocarde sur dix. Revue Medicale De Liege, 59, 676-679.

[39] Li, S.Y., Gao, Y., Ma, W.N., Wang, H.C., Zhou, G., Guo, W.C., et al. (2014) The Relationship between Serum Lipoprotein(a) Levels and Ischemic Stroke Risk: A Cohort Study in the Chinese Population. Inflammation, 37, 686-693. https://doi.org/10.1007/s10753-013-9785-x

[40] Erqou, S., Kaptoge, S., Perry, P.L., Di Angelantonio, E., Thompson, A., White, I.R., et al. (2009) Lipoprotein(a) Concentration and the Risk of Coronary Heart Disease, Stroke, and Nonvascular Mortality. JAMA, 302, 412-423. https://doi.org/10.1001/jama.2009.1063

[41] Nendaz, M.R. and Perrier, A. (2004) Maladie Thromboembolique Veineuse-Un taux de lipoprotéine (a) sérique supérieur à $300 \mathrm{mg} / \mathrm{L}$ est un facteur de risque de thrombose veineuse. Revue des Maladies Respiratoires, 21, 87-88. https://doi.org/10.1016/S0761-8425(04)71988-9

[42] Joussein-Remacle, S., Delarche, N., Bader, H., Lasserre, R. and Estrade, G. (2006) Risk Factors in a Young Population with Acute Myocardial Infarction: One Year Prospective Study. Annales De Cardiologie Et D’ Angeiologie, 55, 204-209. https://doi.org/10.1016/j.ancard.2006.05.001

[43] Kamstrup, P.R. and Nordestgaard, B.G. (2013) Lipoprotein(a) Concentrations, Isoform Size, and Risk of Type 2 Diabetes: A Mendelian Randomisation Study. The 
Lancet, 1, 220-227. https://doi.org/10.1016/S2213-8587(13)70064-0

[44] Forbang, N.I., Criqui, M.H., Allison, M.A., Ix, J.H., Steffen, B.T., Cushman, M., et al. (2016) Sex and Ethnic Differences in the Associations between Lipoprotein(a) and Peripheral Arterial Disease in the Multi-Ethnic Study of Atherosclerosis. Journal of Vascular Surgery, 63, 453-458. https://doi.org/10.1016/j.jvs.2015.08.114

[45] Bennet, A., Di Angelantonio, E., Erqou, S., Eiriksdottir, G., Sigurdsson, G., Woodward, M., et al. (2008) Lipoprotein(a) Levels and Risk of Future Coronary Heart Disease: Large-Scale Prospective Data. Archives of Internal Medicine, 168, 598-608. https://doi.org/10.1001/archinte.168.6.598

[46] Manocha, A. and Srivastava, L.M. (2016) Lipoprotein(a): A Unique Independent Risk Factor for Coronary Artery Disease. Indian Journal of Clinical Biochemistry, 31, 13-20. https://doi.org/10.1007/s12291-015-0483-3

[47] Goussault, Y. (2002) La lipoprotéine(a). Revue Francaise des Laboratoires, 340, 27-29. https://doi.org/10.1016/S0338-9898(02)80101-9

[48] Stone, P.A. and Kazil, J. (2014) The Relationships between Serum C-Reactive Protein Level and Risk and Progression of Coronary and Carotid Atherosclerosis. Seminars in Vascular Surgery, 27, 138-142. https://doi.org/10.1053/j.semvascsurg.2015.04.002

[49] Ridker, P.M. (2016) A Test in Context: High-Sensitivity C-Reactive Protein. Journal of the American College of Cardiology, 67, 712-723.

https://doi.org/10.1016/j.jacc.2015.11.037

[50] Koenig, W. (2013) High-Sensitivity C-Reactive Protein and Atherosclerotic Disease: from Improved Risk Prediction to Risk-Guided Therapy. International Journal of Cardiology, 168, 5126-5134. https://doi.org/10.1016/j.ijcard.2013.07.113

[51] Saito, I., Sato, S., Nakamura, M., Kokubo, Y., Mannami, T., Adachi, H., et al. (2007) A Low Level of C-Reactive Protein in Japanese Adults and Its Association with Cardiovascular Risk Factors: The Japan NCVC-Collaborative Inflammation Cohort (JNIC) Study. Atherosclerosis, 194, 238-244. https://doi.org/10.1016/j.atherosclerosis.2006.07.032

[52] Erem, C., Hacihasanoglu, A., Deger, O., Kocak, M. and Topbas, M. (2008) Prevalence of Dyslipidemia and Associated Risk factors among Turkish Adults: Trabzon Lipid Study. Endocrine, 34, 36-51. https://doi.org/10.1007/s12020-008-9100-z

[53] Chellak, S., Bigaillon, C., El Jahiri, Y., Garcia, C., Ceppa, F., Mayaudon, H., et al. (2005) Homocystéine et paramètres du syndrome métabolique et du risque cardiovasculaire chez 2045 militaires: Etude EPIMIL. Immuno-Analyse \& Biologie Specialisee, 20, 169-172. https://doi.org/10.1016/j.immbio.2005.03.002

[54] De jaegera, C., Fraoucenea, N., Voronskaa, E. and Cherin, P. (2010) Rôle de l'homocystéine en pathologie. Medecine et longévité, 2, 73-86.

https://doi.org/10.1016/j.mlong.2010.03.002 